\title{
Bagaimana Inspeksi, Kontrol dan Supervisi Mempengaruhi Pembinaan dan Pengembangan dari Pengawas Sekolah: Efek pada Kompetensi Kepala Sekolah
}

\author{
Yayah Rahyasih \\ Universitas Pendidikan Indonesia Bandung \\ yayahrahyasih@upi.edu \\ Johar Permana \\ Universitas Pendidikan Indonesia Bandung \\ permanajohar@upi.edu
}

\section{Liah Siti Syarifah}

\author{
Sekolah Tinggi Agama Islam Syamsul 'Ulum Gunungpuyuh Sukabumi \\ liahss@staisyamsululum.ac.id
}

\begin{abstract}
Improving the quality of educational institution requires adequate competence from a school principal to develop of school he leads, to help improve the professionalism of the principal, the government appoints an education supervisor whose job is to carry out managerial supervision. This research aims to reinforce the impact of spectrums of educational supervision in coaching and development for school principals. The present study adopted a quantitative approach through surveys. The population in this study were all school principals in Bandung, whereas the sample was a member of the population taken through a saturation sampling technique of 39 people. Assessed through multiple linear regression analysis, the current research also examined primary sources of data collected through fulfilling the interviews and questionnaires covering three spectrums of surveillance activities (aspects of inspection, control, supervision) as well as coaching and development for school principals. The results of analysis demonstrated that Fcount is 51.7 with a significance level of $0.000 \leq 0.05$. Thus, it can be concluded that the managerial supervision carried out by supervisors with inspection, control and supervision delivers a positive and significant impact in the coaching and development activities of school principals. This report presented the findings of research that supervisory must be proportionate, planned, directed and sustainable.
\end{abstract}

Keywords: Control, educational supervisor, inspection, school principal, supervision

\begin{abstract}
Abstrak: Peningkatan mutu satuan pendidikan membutuhkan kompetensi yang memadai dari seorang kepala sekolah dalam mengembangkan sekolah yang dipimpinnya, untuk membantu meningkatkan kemampuanprofesionalisme kepala sekolah tersebut, pemerintah mengangkat pengawas pendidikan yang salah satu tugasnya adalah melakukan supervisi manajerial. Penelitian ini bertujuan untuk menemukan pengaruh spektrum-spektrum pengawasan pendidikan dalam pembinaan dan pengembangan kepala Sekolah. Penelitian ini menggunakan pendekatan kuantitatif dengan metode survey. Populasi dalam penelitian ini adalah seluruh Kepala Sekolah di Kota Bandung, sedangkan sampelnya adalah anggota populasi yang diambil melalui teknik sampling jenuh berjumlah 39 orang. Data yang digunakan dalam penelitian ini adalah data primer yang diperoleh melalui wawancara dan penyebaran kuesioner yang meliputi tiga spektrum kegiatan kepengawasan (aspek inspeksi, kontrol, supervisi) serta pembinaan dan pengembangan kepala
\end{abstract}


sekolah. Teknik analisis data yang digunakan adalah analisis regresi linier berganda. Hasil analisis menunjukan bahwa F Hitung sebesar 51,7 dengan tingkat signifikansi $0,000 \leq 0,05$. Dengan demikian dapat disimpulkan bahwa pengawasan managerial yang dilakukan pengawas dengan inspeksi, kontrol dan supervisi secara bersamasama berpengaruh positif dan signifikan dalam kegiatan pembinaan dan pengembangan kepala sekolah. Hasil penelitian tersebut mengimplikasikan bahwa pengawasan managerial harus dilakukan secara proporsional, terencana, terarah dan berkelanjutan.

Kata Kunci: Inspeksi, Kepala Sekolah, Kontrol, Pengawas Pendidikan, Supervisi

\section{PENDAHULUAN}

Kepala sekolah memiliki peran yang sangat strategis dalam peningkatan kualitas pendidikan (Alfian, 2019) terutama berkaitan dengan upaya pengembangan sekolah. Sebagaimana menurut Syarifah (2019) bahwa Keberhasilan Kepala Sekolah dalam memimpin sekolahnya, berbanding lurus dengan keberhasilan sekolah dalam menyelenggarakan pendidikan yang baik. Sebagai konsekuensi dari pelaksanaan peningkatan mutu pendidikan tersebut dibutuhkan manajerial yang cukup memadai dari kepala sekolah dalam mengelola sekolah.

Sejalan hal di atas, pandangan Ki Hajar Dewantara bahwa kepala sekolah harus mampu menjalankan fungsi "Ïng Ngarso Sung Tulodo" mengisyaratkan perlunya ia memiliki karakter yang kuat dan mampu membawa perubahan untuk kemajuan sekolah. Berdasarkan hal di atas, diperlukan pengembangan kemampuan profesionalisme kepala sekolah yang dilaksanakan secara terus menerus dan terencana.

Untuk membantu kepala sekolah dalam meningkatkan kemampuan profesionalismenya pemerintah telah mengangkat pengawas pendidikan yang salah satu tugasnya adalah melakukan supervisi manajerial. Hal tersebut sebagaimana Keputusan Menteri Negara Pendayagunaan Aparatur Negara dan Reformasi Birokrasi Nomor 21 Tahun 2010 tentang Jabatan Fungsional Pengawas Sekolah dan Angka dijelaskan bahwa pengawas sekolah adalah Pegawai Negeri Sipil (PNS) yang diberi tugas, tanggung jawab dan wewenang secara penuh oleh pejabat yang berwenang untuk melaksanakan pengawasan akademik dan manajerial pada satuan pendidikan.

Secara umum, supervisi berarti kegiatan yang dilakukan oleh pengawas satuan pendidikan dalam rangka membantu kepala sekolah, guru dan tenaga kependidikan lainnya guna meningkatkan mutu dan efektivitas penyelenggaraan pendidikan dan pembelajaran (http://lppks.kemdikbud.go.id, 2020). Lebih lanjut supervisi manajerial merupakan kegiatan profesional yang dilakukan oleh pengawas sekolah yang berkenaan dengan aspek pengelolaan sekolah yang terkait langsung dengan peningkatan efisiensi dan efektivitas sekolah yang 
mencakup perencanaan, koordinasi, pelaksanaan, penilaian, pengembangan kompetensi sumber daya manusia (SDM) kependidikan dan sumberdaya lainnya (Dirjen PMPTK Depdiknas, 2009). Berdasarkan pengertian di atas, pelaksananaan supervisi manajerial ini secara umum bertujuan untuk meningkatkan mutu dan efektivitas penyelenggaraan pendidikan dan pembelajaran di sekolah.

Namun saat ini pemerintah pusat mewacanakan penghapusan pengawas sekolah (Jaringan Pemberitaan Nusantara Negeriku, 2019; Radar Bekasi, 2019; Detik, 2019), hal tersebut diindikasikan karena peran pengawas sekolah dalam praktik pendidikan belum banyak kelihatan dan mereka hanya terjebak pada kerja-kerja yang bersifat formalitas dan administratif, sehingga pada akhirnya dianggap beban.

Wacana penghapusan jabatan pengawas ini seakan-akan menafikan peran pengawas dalam sistem pendidikan dan hal ini sangat kontradiktif dengan beberapa hasil penelitian tentang peran pengawas khususnya dalam supervisi manajerial.

Ismail (2016) menemukan bahwa pengawasan pendidikan merupakan salah satu dukungan terpenting bagi sistem pendidikan, tiga faktor signifikansi untuk pengawasan pendidikan yaitu pengajaran \& pembelajaran, etika digital serta pelatihan dan pengembangan profesional.

Emgiek dkk (2018) membuktikan bahwa supervisi manajerial dari pengawas sekolah berpengaruh positif dan signifikan terhadap kinerja kepala sekolah.

Menurut LPPKS Kemdikbud (2020) supervisi manajerial ini menitikberatkan pengamatan pada aspek-aspek pengelolaan dan administrasi sekolah yang berfungsi sebagai pendukung (supporting) terlaksananya pembelajaran.

Beranjak dari masalah dan penelitian-penelitian terdahulu, penelitian ini bertujuan untuk menganalisis efektifitas pelaksanaan pengawasan pendidikan (khususnya dalam konteks supervisi manajerial) berdasarkan tiga spektrum (pengawasan) yang meliputi inspeksi, kontrol dan supervisi (Satori, 2016).

Upaya ini diharapkan menjadi bahan mendasar dalam mendesain model pegawasan manajerial yang ideal dalam membina dan mengembangkan kepala sekolah di masa depan.

\section{METODE PENELITIAN}

Penelitian ini menggunakan pendekatan kuantitatif dengan menggunakan metode survey (Suryani \& Dhiki, 2020). Penelitian dilaksanakan 
pada April-Desember 2020 di SMP Sekota Bandung. Populasi penelitian adalah Kepala Sekolah SMP di Kota Bandung yang menurut data dari Dinas Kabupaten Bandung berjumlah 52 sekolah, sedangkan sampel yang diambil berjumlah 39 kepala sekolah. Adapun teknik pengambilan sampel yang digunakan dalam penelitian ini adalah simple random sampling yaitu teknik pengambilan sampel secara acak tanpa memperhatikan strata yang ada dalam populasi.

Jenis data dalam penelitian ini adalah data primer yang didapat melalui pengisian kuesioner dan wawancara di mana data yang diambil berupa tanggapan responden dan/ atau narasumber terkait pelaksanaan pengawasan berdasarkan tiga spektrum (pengawasan) yang meliputi inspeksi $\left(\mathrm{X}_{1}\right)$, kontrol $\left(\mathrm{X}_{2}\right)$ dan supervisi $\left(\mathrm{X}_{3}\right)$ dan pembinaan dan pengembangan kepala sekolah $(\mathrm{Y})$.

Pengambilan data melalui wawancara dilakukan kepada 2 narasumber dari sekolah yang berbeda. Sedangkan untuk pengambilan data melalui kuesioner dilakukan kepada sejumlah sampel penelitian yang berjumlah 39 Kepala Sekolah SMP di Kota Bandung dan kuesioner yang disebar telah melalui uji validitas dan reliabilitas instrumen.

Setelah data terkumpul, kemudian diolah dan dianalisis. Pengolahan data yang didapat melalui kuesioner dibantu dengan aplikasi SPSS. 25. Pada tahap analisis data dilakukan pengujianasumsi klasik dan pengujian hipotesis.

Uji asumsi klasik dilakukan sebagai prasyarat untuk mendapatkan model regresi yang baik, dalam penelitian ini dilakukan uji normalitas, uji multikolinieritas, uji heteroskedastisitas, uji autokorelasi dan uji linearitas.

Setelah semua syarat untuk ditelitinya suatu model regresi terpenuhi semua, dilakukan uji hipotesis dengan melakukan uji simultan (uji F) untuk mengetahui apakah semua variabel bebas berpengaruh secara signifikan terhadap variabel terikat.

Begitupula dengan data dari hasil wawancara yang sangat berguna dalam memperkuat hasil analisis data kuantitatif yaitu melengkapi dan memperdalam informasi.

Adapun hipotesis yang diajukan dalam penelitian ini terdiri dari hipotesis awal $\left(\mathrm{H}_{0}\right)$ dan hipotesis alternatif $\left(\mathrm{H}_{1}\right)$ yaitu sebagai berikut:

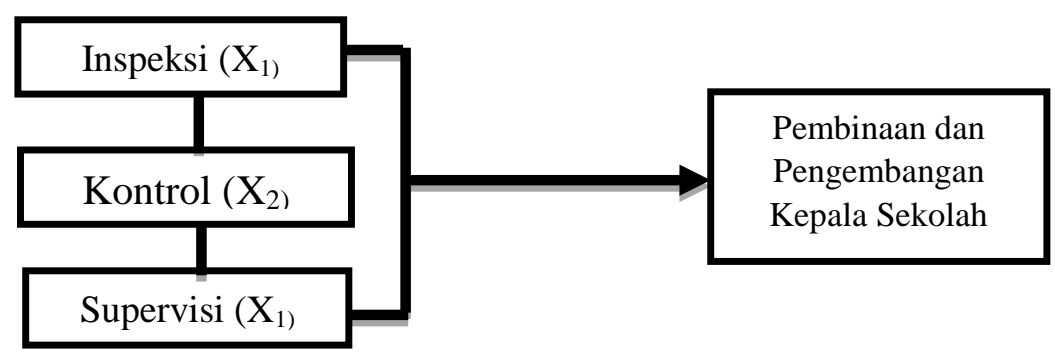

Gambar 1. Hipotesis Penelitian 
$\mathrm{H}_{0}$ : Variabel inspeksi, kontrol dan supervisi tidak berpengaruh positif dan signifikan secara bersama-sama dalam membina dan mengembangkan kepala sekolah.

$\mathrm{H}_{1}$ : Variabel inspeksi, kontrol dan supervisi berpengaruh positif dan signifikan secara bersama-dalam membina dan mengembangkan kepala sekolah.

\section{HASIL DAN PEMBAHASAN}

Tujuan penelitian ini adalah untuk menganalisis efektifitas pelaksanaan pengawasan berdasarkan tiga spektrum (pengawasan) yang meliputi inspeksi, kontrol dan supervisi.

\section{A. Uji Asumsi Klasik}

Sebelum dilakukan uji hipotesis, peneliti melakukan uji asumsi klasik terlebih dahulu. Adapun pengujian ini terdiri dari uji normalitas, uji multikolinieritas, uji heteroskedastisitas, uji autokorelasi dan uji linearitas. Hasil uji asumsi klasik sebagai berikut:

1. Uji Normalitas

Uji normalitas dilakukan dengan menggunakan statistic kolomogrovsmirnov. Menurut Ghazali (2011), jika taraf siginifikansi $>0,05$ maka model regresi berdistribusi normal. berikut hasil uji normalitas:

Tabel 1. Uji Normalitas

\begin{tabular}{cccccc}
\hline No & $\begin{array}{c}\text { Model Regresi } \\
\text { Berganda }\end{array}$ & $\begin{array}{c}\text { Standar } \\
\text { Data } \\
\text { Normal }\end{array}$ & $\begin{array}{c}\text { Taraf } \\
\text { Signifikansi }\end{array}$ & Keputusan & Keterangan \\
\hline 1 & $\begin{array}{c}\text { Model Regresi } \\
\text { Berganda }\end{array}$ & 0,05 & 0,2 & $0,2>0,05$ & Normal \\
\hline
\end{tabular}

Sumber: Data Olahan

Berdasarkan uji normalitas pada tabel di atas diketahui nilai signifikansi $0,2>0,05$, sehingga model regresi berdistribusi normal. Dengan kata lain, model regresi ini layak dipakai karena memenuhi asumsi normalitas.

2. Uji Multikolenieritas

Uji multikolinearitas dilakukan dengan menggunakan model tolerance dan VIF. Menurut Ghazali (2011) tidak ada gejala multikolinearitas, jika nilai tolerance $>0,100$ dan VIF $<10,00$. Berikut hasil uji multikolinearitas: 
Tabel 2. Uji Multikolenieritas

\begin{tabular}{ccccccc}
\hline No & Prediktor & $\begin{array}{c}\text { Standar } \\
\text { Nilai } \\
\text { Tolerance }\end{array}$ & $\begin{array}{c}\text { Nilai } \\
\text { Tolerance }\end{array}$ & $\begin{array}{c}\text { Standar } \\
\text { Nilai } \\
\text { VIF }\end{array}$ & $\begin{array}{c}\text { Nilai } \\
\text { VIF }\end{array}$ & Keterangan \\
\hline 1 & Inspeksi $\left(\mathrm{X}_{1}\right)$ & 0,1 & 0,486 & 10 & 2,058 & $\begin{array}{c}\text { Tidak ada gejala } \\
\text { multikolinearitas }\end{array}$ \\
\hline 2 & Kontrol $\left(\mathrm{X}_{2}\right)$ & 0,1 & 0,432 & 10 & 2,317 & $\begin{array}{c}\text { Tidak ada gejala } \\
\text { multikolinearitas }\end{array}$ \\
\hline 3 & Supervisi $\left(\mathrm{X}_{3}\right)$ & 0,1 & 0,386 & 10 & 2,591 & $\begin{array}{c}\text { Tidak ada gejala } \\
\text { multikolinearitas }\end{array}$ \\
\hline
\end{tabular}

Sumber: Data Olahan

Berdasarkan uji multikolinearitas pada tabel di atas diketahui nilai tolerance $>0,100$ dan VIF $<10$, maka dapat disimpulkan bahwa pada model regresi ini tidak ada gejala multikolinearitas.

3. Uji Heterokedastisitas

Uji heterokedastisitas dilakukan dengan menggunakan model scatterplots, berikut hasilnva:

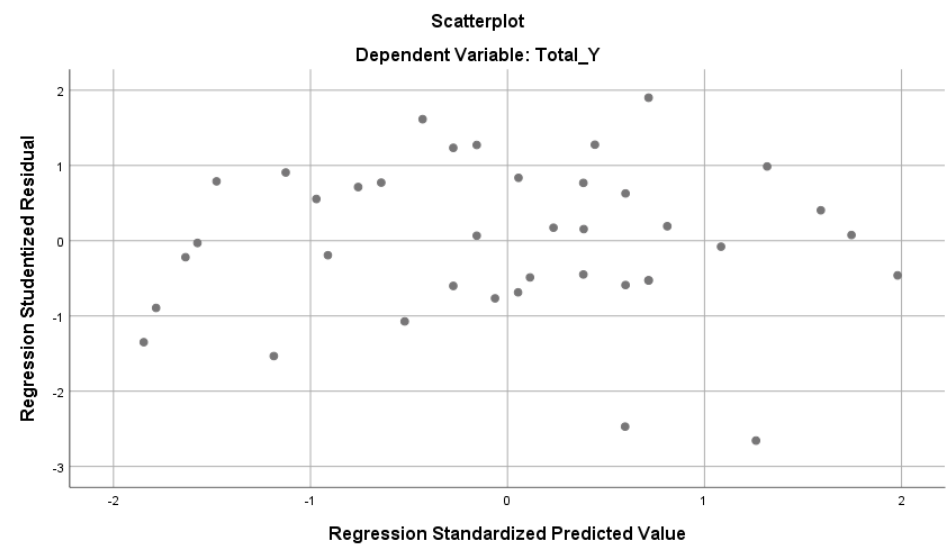

Gambar 2. Uji Heterokedastisitas

Berdasarkan uji heterokedastisitas pada gambar di atas diketahui bahwa tidak ada pola yang jelas pada gambar scatterplots dan titik-tik menyebar di atas dan di bawah angka 0 pada sumbu Y (Ghozali, 2011), sehingga dapat disimpulkan bahwa pada model regresi ini tidak ada gejala heterokedastisitas.

4. Uji Auto Korelasi

Uji auto korelasi dilakukan dengan menggunakan teknik durbin watson. Berdasarkan pendapat Ghozali (2011) bahwa gejala autokorelasi tidak akan 
terjadi jika nilai durbin watson terletak antar du sampai dengan (4-du). Berikut hasil uji auto korelasi:

Tabel 3. Uji Auto Korelasi

\begin{tabular}{ccccccc}
\hline No & Model Regresi & $\begin{array}{c}\text { Nilai } \\
\text { du }\end{array}$ & $\begin{array}{c}\text { Durbin- } \\
\text { Watson }\end{array}$ & 4-du & Keputusan & Ket \\
\hline 1 & $\begin{array}{l}\text { Pembinaan dan } \\
\text { Pengembangan }\end{array}$ & 1,657 & 1,736 & 2,343 & $\begin{array}{c}\text { du }< \\
\text { Durbin } \\
\text { Watson }< \\
\text { 4-du }\end{array}$ & $\begin{array}{c}\text { Tidak ada } \\
\text { gejala } \\
\text { auto } \\
\text { korelasi }\end{array}$ \\
\hline
\end{tabular}

Sumber: Data Olahan

Nilai tabel Durbin Watson berdasarkan K (3) dan N (39) dengan signifikansi 5\% adalah 1,657. Berdasarkan tabel di atas, nilai du $(1,657)<$ Durbin Watson $(1,736)<4$-du (2,343), sehingga dapat disimpulkan bahwa pada model regresi ini tidak ada gejala autokorelasi.

\section{Uji Linearitas}

Uji linearitas bertujuan untuk mengetahui apakah dua variabel atau lebih memiliki hubungan yang linear atau tidak secara signifikan. Menurut Ghazali (2011), jika nilai signifikansi > 0,05 maka arah regresi dari variabel bebas ke variabel terikat bersifat linear. Hasil uji linearitas dalam penelitian ini sebagai berikut:

Tabel 4. Uji Linieritas

\begin{tabular}{cccccc}
\hline No & $\begin{array}{c}\text { Model Regresi } \\
\text { Berganda }\end{array}$ & $\begin{array}{c}\text { Standar } \\
\text { Data } \\
\text { Normal }\end{array}$ & $\begin{array}{c}\text { Taraf } \\
\text { Signifikansi }\end{array}$ & Keputusan & Keterangan \\
\hline 1 & $\begin{array}{c}\text { Model regresi } \\
\text { berganda }\end{array}$ & 0,05 & 0,108 & $0,108>0,05$ & Linear \\
\hline
\end{tabular}

Sumber: Data Olahan

Berdasarkan tabel di atas, diketahui nilai sig. deviation from linearity sebesar $0,108>0,05$, hal tersebut menunjukan bahwa terdapat hubungan yang linear antara variabel inspeksi, kontrol dan supervisi dalam kegiatan pembinaan dan pengembangan kepala sekolah.

Berdasarkan uji asumsi klasik yang telah dilakukan, model regresi dalam penelitian ini distribusi datanya normal, linear, juga tidak adagejala multikolinieritas, heteroskedastisitas, dan autokorelasi, sehingga bisa dikatakan bahwa semua syarat untuk ditelitinyasuatu model regresi telah semua terpenuhi. 


\section{B. Uji Regresi Linear Berganda}

Berdasarkan pengolahan data dengan menggunakan SPSS 25, diketahui output hasil pengolahan data sebagai berikut:

Tabel 5. Uji Regresi Linear Berganda

\begin{tabular}{cccrc}
\hline No & Prediktor & $\begin{array}{c}\text { Koefisien } \\
\text { Regresi }\end{array}$ & P Value & Keterangan \\
\hline 1 & Inspeksi $\left(\mathrm{X}_{1}\right)$ & -0.400 & 0.330 & Negatif tidak signifikan \\
\hline 2 & Kontrol $\left(\mathrm{X}_{2}\right)$ & 2.262 & 0.000 & Positif signifikan \\
\hline 3 & Supervisi $\left(\mathrm{X}_{3}\right)$ & 1.848 & 0.000 & Positif signifikan \\
\hline
\end{tabular}

Sumber: Data Olahan

Berdasarkan tabel di atas, maka hanya terdapat 2 variabel yang signifikan pada nilai tingkat kepercayaan $(\alpha) 5 \%$ atau 0,05 , sehingga dapat disusun persamaan regresi terkait spektrum pengawasan yang berpengaruh dalam proses pembinaan dan pengembangan kepala sekolah yaitu variabel inspeksi $\left(\mathrm{X}_{1}\right)$, kontrol $\left(\mathrm{X}_{2}\right)$ dan supervisi $\left(\mathrm{X}_{3}\right)$ sebagai berikut:

$$
\mathrm{Y}=-5.885-0.4 \mathrm{X}_{1}+2.262 \mathrm{X}_{2}+1.848 \mathrm{X}_{3}
$$

Nilai koefisien untuk variabel independen inspeksi $\left(X_{1}\right)$ bernilai negatif sebesar -0.400 hal ini menunjukkan bahwa dengan mengasumsikan diabaikannya variabel independen lainnya, jika variabel inspeksi mengalami peningkatan 1\%, maka dapat mempengaruhi penurunan kefektifan pembinaan dan pengembangan kepala sekolah sebesar 0.400 .

Nilai koefisien untuk variabel independen kontrol $\left(\mathrm{X}_{2}\right)$ bernilai positif sebesar 2.262, hal ini menunjukkan bahwa dengan mengasumsikan diabaikannya variabel independen lainnya, jika variabel kontrol meningkat sebesar $1 \%$, maka dapat mempengaruhi kefektifan pembinaan dan pengembangan kepala sekolah.

Nilai koefisien untuk variabel independen supervisi $\left(\mathrm{X}_{3}\right)$ bernilai positif sebesar 1.848, hal ini menunjukkan bahwa dengan mengasumsikan diabaikannya variabel independen lainnya, jika variabel supervisi meningkat sebesar $1 \%$, maka dapat mempengaruhi kefektifan pembinaan dan pengembangan kepala sekolah.

Tabel 6. Uji Koefisien Determinasi

\begin{tabular}{lccc}
\hline No & \multicolumn{1}{c}{ Prediktor } & \multicolumn{1}{c}{ Rsquare } & Keterangan \\
\hline \multirow{2}{*}{1} & Inspeksi $\left(\mathrm{X}_{1}\right)$, Kontrol & 0,816 atau & Pengaruh variable \\
& $\left(\mathrm{X}_{2}\right)$ dan Supervisi $\left(\mathrm{X}_{3}\right)$ & $81,6 \%$ & $\begin{array}{c}\text { independen terhadap variable } \\
\text { dependen }\end{array}$ \\
\hline
\end{tabular}

Sumber: Data Olahan 
Berdasarkan tabel 3 dapat dijelaskan bahwa nilai R2 (R square) sebesar 0.816 atau $81,6 \%$. Hal ini menunjukkan bahwa prosentase sumbangan pengaruh variabel independen $\left(\mathrm{X}_{1}, \mathrm{X}_{2}\right.$, dan $\left.\mathrm{X}_{3}\right)$ yaitu inspeksi, kontrol dan supervisi dalam proses pembinaan dan pengembangan kepala sekolah $(\mathrm{Y})$ adalah sebesar 81,6 \%. Sedangkan sisanya sebesar $18,4 \%$ dipengaruhi oleh variabel lain yang tidak dimasukkan dalam model penelitian.

\section{Uji Hipotesis}

Setelah syarat untuk ditelitinya suatu model regresi terpenuhi semua, langkah selanjutnya untuk mengetahui diterima atau tidaknya hipotesis yang diajukan yaitu dengan melakukan uji simultan (uji F).

Uji Simultan (uji F) dilakukan untuk menemukan pengaruh secara simultan dari variabel inspeksi $\left(\mathrm{X}_{1}\right)$, kontrol $\left(\mathrm{X}_{2}\right)$ dan supervisi $\left(\mathrm{X}_{3}\right)$ dalam proses pembinaan dan pengembangan kepala Sekolah (Y). Menurut Ghozali (2011), jika nilai siginifikansi lebih kecil dari pada 0,05 atau nilai $\mathrm{F}_{\text {hitung }}$ lebih besar dari pada $\mathrm{F}_{\text {tabel}}$, maka $\mathrm{H} 0$ ditolak Berikut hasil perhitungannya:

Tabel 7. Uji Simultan (Uji F)

\begin{tabular}{cccccc}
\hline No & Prediktor & $\mathbf{F}_{\text {hitung }}$ & $\mathbf{F}_{\text {tabel }}$ & P-value & Keterangan \\
\hline \multirow{2}{*}{1} & $\begin{array}{l}\text { Variabel Inspeksi } \\
\left(\mathrm{X}_{1}\right), \text { Kontrol }\left(\mathrm{X}_{2}\right) \\
\text { dan Supervisi }\left(\mathrm{X}_{3}\right)\end{array}$ & 51,703 & 2.87 & 0,000 & $\begin{array}{c}\text { Positif dan } \\
\text { signifikan }\end{array}$ \\
\hline
\end{tabular}

Sumber: Data Olahan

Berdasarkan uji $\mathrm{F}$ pada tabel di atas bahwa nilai signifikansi $0,000<0,05$ dan $\mathrm{F}_{\text {hitung }}>\mathrm{F}_{\text {tabel }}$ sehingga $\mathrm{H}_{0}$ ditolak, dengan demikian terbukti bahwa kegiatan kepengawasan dengan inspeksi, kontrol dan supervisi secara simultan berpengaruh positif dan signifikan dalam membina dan mengembangkan kepala sekolah.

Pengawasan managerial pada kepala sekolah merupakan layanan profesional untuk meningkatkan dan mengoptimalkan kinerja kepala sekolah (Purwanto, 2016). Sebagaimana hasil penelitian tindakan sekolah dari Solikin (2020) yang menemukan bahwa supervisi manajerial telah meningkatkan kompetensi dalam menyusun instrumen danmelakukan supervisi kelas yang mana pada siklus I diperoleh hasil $81 \%$, peserta memahami supervisi kelas tetapi tidak dapat mengimplementasikannya berdasarkan karakteristik yang ada. Pada Siklus II terjadi peningkatan pemahamandari (siklus I) 29,90\% rata-rata mencapai skor menjadi 45,47\%. Pada Siklus III terjadi peningkatan pengawasankompetensi, dari rata-rata (siklus II) sebesar 45,47\% mencapai skor menjadi $50,42 \%$. 
Inspeksi, kontrol dan supervisi adalah istilah yang terkandung dalam pengawasan itu sendiri yang memiliki perbedaaan penggunaan dan harus diterapkan secara proporsional. Sebagaimana menurut Satori (2016) pengawasan dengan pendekatan inspeksi bertujuan untuk membentuk "kepatuhan legal" yaitu kepatuhan terhadap norma-norma kerja yang bersumber pada dokumen hukum dan ketentuan kelembagaan yang mengikat, sedangkan pengawasan dengan pendekatan kontrol dimaksudkan untuk membangun "kepatuhan manajerial" yaitu kepatuhan terhdapa pelaksanaan fungsi-fungsi manajemen, terakhir pengawasan dengan pendekatan supervisi memiliki esensi untuk mendorong "kepatuhan profesional" yaitu pelaksanaan pekerjaan yang didasarkan atas konsep, teori dan refleksi praktik yang benar.

Pengaruh positif dan signifikan secara bersama-sama dalam kegiatan kepengawasan dengan inspeksi, kontrol dan supervisi dalam membina dan mengembangkan kepala sekolah, mengimplikasikan bahwa dalam prakteknya pengawas seyogiyanya mampu mengombinasikan pendekatan-pendekatan tersebut dalam membina dan mengembangkan kepala sekolah secara proporsional. Namun pengawas hendaknya lebih meminimalisir pendekatan inspeksi dalam melaksanakan tugas pembinaan dan pengembangan kepala sekolah, karena dari hasil uji koefisien determinasi diketahui bahwa variabel independen inspeksi (X1) bernilai negatif sebesar -0.400, gambarannya (dengan mengasumsikan diabaikannya variabel independen lainnya) jika variabel inspeksi mengalami peningkatan 1\%, maka mempengaruhi penurunan kefektifan pembinaan dan pengembangan kepala sekolah sebesar 0.400 .

Mengingat pentingnya pengawasan managerial sebagaimana penelitian di atas, maka kita perlu memahami peran seorang pengawas sekolah. supervisor memiliki banyak peran. Ini mencakup sebagai berikut: Kolaborator dan negosiator dalam proses perencanaan, koordinator pengembangan sekolah, asesor dalam mengidentifikasi kelemahan dan menganalisis potensi sekolah, menjadi pusat informasi sekolah pengembangan kualitas, dan sebagai evaluator dalam menafsirkan hasil pengawasan untuk tindaklanjut dalam kegatan pengawasan selanjutnya (Dirjen PMPTK Depdiknas, 2009).

Di sisi lain, menurut Peraturan Menteri Pendidikan Nasional Nomor 13 Tahun 2007 tentang Standar Kepala Sekolah/ Madrasah dijelaskan bahwa ada lima kompetensi yang harus dikuasi oleh seorang kepala sekolah yaitu kompetensi kepribadian, kompetensi manajerial, kompetensi kewirausahaan, kompetensi supervisi, dan kompetensi sosial. Berikut penjelasannya (Daryanto \&Tasrial, 2015):

1. Kompetensi kepribadian. Dalam kompetensi kepribadian, kepala sekolah harus berakhlak mulia, menjadi teladan, integritas sebagai pemimpin, 
pengembangan diri, mengendalikan diri dalam mengahdapi masalah serta memiliki bakat dan minat jabatan sebagai pemimpin pendidikan.

2. Kompetensi manajerial. Dalam kompetensi manaterial, kepala sekolah harus mampu menyusun perencanaan sekolah, mengembangkan sekolah, memimpin sekolah, mengelola perubahan, menciptakan budaya dan iklim sekolah yang kondusif dan inovatif bagi pembelajaran, mengelola guru dan staf, mengelola sarana dan prasarana sekolah, mengelola hubungan sekolah, mengelola peserta didik, mengelola pengembangan kurikulum dan kegiatan pembelajaran, mengelola keuangan sekolah, mengelola ketatausahaan sekolah, mengelola unit layanan khusus sekolah, mengelola sistem informasi sekolah, memanfaatkan kemajuan teknologi dan informasi serta melakukan monitoring, evaluasi dan pelaporan pelaksanaan program kegiatan sekolah.

3. Kompetensi kewirausahaan. Dalam kompetensi kewirausahaan, kepala sekolah harus mampu memahami dan menghayati arti serta tujuan perubahan (inovasi) sekolah, menggunakan metode, teknis dan proses perubahan sekolah, menumbuhkan iklim yang mendorong kebebasan berfikir untuk menciptakan kreatifitas dan inovasi, mendorong warga sekolah untuk melakukan eksperikem dalam melakukan hal-hal baru, menghargai hasil-hasil kreativitas warga sekolah dengan memberikan rewards dan menumbuhkan jiwa kewirausahaan warga sekolah.

4. Kompetensi supervisi. Dalam kompetensi supervisi, kepala sekolah harus mampu merencanakan supervisi akademik untuk guru, melaksanakan supervisi akademik dengan pendekatan dan teknik yang tepat dan menindaklanjuti hasil supervisi akademik.

5. Kompetensi sosial. Dalam kompetensi supervisi, kepala sekolah harus mampu menerapkan dan mengembangkan nilai-nilai kehidupan sekolah yang demokratis, membentuk budaya kerja sama yang kuat, menumbuhkan budaya profesionalisme warga sekolah, menciptakan iklin sekolah yang kondusifakademis dan menumbuh-kembangkan keragaman budaya dalam kehidupan sekolah.

Ekawaty dkk (2018) menjelaskan bahwa pelaksanaan supervisi manajerial perlu dikoordinasi dengan baik, supervisi manajerial yang terkoordinasi baik dengan setiap pengelola sekolah binaan inilah yang berdampak pada peningkatan mutu pendidikan padasatuan pendidikan. Selain itu, setelah dilakukan koordinasi, setidaknya supervisi manajerial dilakukan melalui tahapan perencanaan, pelaksanaan, evaluasi, follow up dan pelaporan (Utomo dkk, 2020). Tahapan tersebut digunakan sebagai guide line, bukan mengarahkan pada pelaksanaan supervisi yang tidak fleksibel, dalam pelaksanaannya tindakan pengawasan hendaknya dilakukan dengan praktik yang reflektif (Sergiovanni, 1985) sehingga benar-benar akan berpengaruh pada performance kepala sekolah. 
Berkaitan dengan hal di atas, diperlukan pelatihan yang paling sesuai untuk orang yang tepat pada waktu yang tepat dengan melakukan Analisis Kebutuhan Pelatihan/ Training Need Analysis (Ismail, 2018) misalnya dengan metode CUDBAS. Hal yang tidak kalah penting adalah pengawas juga perlu mengembangkan strategi yang tepat, misalnya supervisi manajerial dalam membuat rencana kerja madrasah/ sekolah bisa menggunakan beberapa strategi di antaranya monitoring dan evaluasi, Focus Group Discussion (FGD), metode delphie, dan tagihan (Suryadi, 2018).

\section{KESIMPULAN}

Berdasarkan hasil penelitian dapat disimpulkan bahwa 81,6 \% faktorfaktor kefektipan kegiatan pengawasan dalam membina kepala sekolah dapat dijelaskan oleh inspeksi, kontrol dan supervisi, sedangkan 18,4\% dipengaruhi oleh variabel lain yang tidak diteliti. Variabel-variabel yang mempengaruhi peningkatan keefektifan kegiatan pembinaan dan pengembangan kepala sekolah yaitu varibel kontrol dan supervisi, sedangkan variabel-variabel yang mempengaruhi penurunan keefektifan pembinaan dan pengembangan kepala sekolah yaitu variabel inspeksi.

\section{UCAPAN TERIMA KASIH}

Paper ini merupakan salah satu luaran penelitian yang didanai Sekolah Pascasarjana Universitas Pendidikan Indonesia (UPI) dalam hibah penelitian Sekolah Pascasarjana Universitas Pendidikan Indonesia (UPI) tahun 2020. Tim peneliti mengucapkan terima kasih atas dukungan semua pihak yaitu Sekolah Pascasarjana Universitas Pendidikan Indonesia (UPI), Dinas Pendidikan Kota Bandung, seluruh responden dan/atau narasumber dan pihak-pihak lain yang telah menyumbangkan waktu dan komitmennya untuk penelitian ini sehingga menjadi hasil penelitian yang dapat dipertanggungjawabkan.

\section{REFERENSI}

Alfian., Wiyono, B. B., Imron., Arifin, I \& Humaisi, M, S. (2019). Development of the Supervision Model Based on Clinical Approach to Increase Managerial Competence of School Principal. Universal Journal of Educational Research 7(11), 2472-2481.

Daryanto \&Tasrial. (2015). Pengembangan Karir Profesi Guru. Yogyakarta: Penerbit Gava Media.

Detik. (2019). Pengamat: Pengawas Sekolah Selayaknya Dihapus. Diakses dari https://news.detik.com/kolom/d-4774142/usulan-penghapusanjabatan-pengawas-sekolah pada 10 September 2020. 
Dirjen PMPTK Depdiknas. (2009). Bahan Belajar Mandiri Musyawarab Kerja Pengawas Sekolah. Jakarta: Drektorat Jenderal Peningkatan Mutu Pendidik dan Tenaga Kependidikan.

Ekawaty, A. E., Khairuddin \& Ibrahim, S. (2018). Pelaksanaan Supervisi Manajerial oleh Pengawas Sekolah dalam Meningkatkan Mutu Pendidikan Di SDN 3 Percontohan Peusangan Kabupaten Bireuen. Jurnal Magister Administrasi Pendidikan Pascasarjana Universitas Syiah Kuala, 6 (3), 183-191.

Emgiek, R. A., Sutarto, J \& Prihatin, T. (2018). The Effect of Managerial Supervision on School Supervisors, Competence, and Achievement Motivation on The Performance of Primary School Principals at The Dikbud Office Kec. Adiwerna Kab. Tegal. Educational Management, 7 (1), $46-51$.

Ismail, I. B. (2018). An important role of educational supervision in the digital age. The International Journal of Counseling and Education, 3 (4), 115-120.

Jaringan Pemberitaan Nusantara Negeriku. (2019). 3 Alasan Dukung Usulan Penghapusan Jabatan Pengawas Sekolah. Diakses dari di https://www.jpnn.com/news/3-alasan-dukung-usulan-penghapusanjabatan-pengawas-sekolah pada 10 September 2020.

LPPKS Kemdikbud. (2020). Konsep Supervisi Manajerial. Diakses dari http://lppks.kemdikbud.go.id/id/kabar/konsep-supervisi-manajerial pada 11 Oktober 2020.

Peraturan Menteri Pendidikan Nasional Nomor 13 Tahun 2007 tentang Standar Kepala Sekolah/ Madrasah.

Radar Bekasi. (2019). Pengamat: Pengawas Sekolah Selayaknya Dihapus. Diakses dari https://radarbekasi.id/2019/11/08/pengamat-pengawas-sekolahselayaknya-dihapus/ pada 10 September 2020.

Satori, D. (2016). Pengawasan dan Penjaminan Mutu Pendidikan. Bandung: Alfabeta.

Sergiovanni, T. J. (1985). Lanscapes, Mindscapes, and Reflective Practices in Supervision. Journal of Curriculum oand Supervision, 1 (1), 5-17.

Solikin, S. (2020). The Improvement of School Principal Performance of SMP Sampang through Managerial Supervision. International Research-Based Education Journal, 2 (1), 9-14.

Suryadi, R. A. (2018). The Strategic of Managerial Supervision in The Forming of the Madrasah Work Plan. Edukasi, 06 (01), 001 - 017. 
268 | Tadbir : Jurnal Studi Manajemen Pendidikan, Vol. 4, No. 2, 2020

Suryani, L \&Dhiki, Y. Y. (2020). Pengaruh Media Pembelajaran terhadap Hasil Belajar Geometri Ruang pada Mahasiswa Program Studi Pendidikan Matematika. JUPIKA: Jurnal Pendidikan Matematika Universitas Flores, 3 (2), $71-80$.

Syarifah, L. S. (2019). Implementasi Pendidikan Karakter: Sebuah Kajian Ilmiah dari Perspektif Gaya Kepemimpinan Kepala Sekolah. NIZAMUL ILMI: Jurnal Manajemen Pendidikan Islam, 4(1), 1-21 